\title{
The Snow Vole and Tatra Marmot as Different Rodent Bioindicators of Lead Pollution in an Alpine Environment: A Hibernation Effect
}

\author{
Marián Janiga1, Zuzana Ballová1*, Mária Angelovičová1 ${ }^{1}$, Ján Korňan² \\ ${ }^{1}$ Institute of High Mountain Biology, University of Žilina, Slovakia \\ ${ }^{2}$ Administration of the Kysuce Protected Landscape Area, Čadca, Slovakia
}

Received: 6 March 2018

Accepted: 12 July 2018

\begin{abstract}
We compared the content of lead $(\mathrm{Pb})$ and other trace metals in various bone and tooth tissues of two alpine rodent species with different behaviours. Hibernating marmots accumulated less $\mathrm{Pb}$ than the non-hibernating and shorter-lived snow voles. It was confirmed that calcium (Ca) is substituted by $\mathrm{Pb}$ in Tatra marmot teeth and skull bones. Ca concentration in marmot bones is likely maintained even during this inactive period and this mechanism may reduce $\mathrm{Pb}$ accumulation in bones of hibernating marmots. $\mathrm{Pb}$ accumulation in bone and tooth tissues may be slightly mitigated by zinc content and also by increased strontium (Sr) in bones. Trace metals deposited differently in tooth and skull bone tissues of marmots. Frontal and parietal skull bones contained significantly more $\mathrm{Pb}$ than marmot incisors, but the difference was not significant when comparing skull bones with molars. Molars are static and could reflect past exposure of heavy metals, whereas incisors renew themselves, and would not.
\end{abstract}

Keywords: Chionomys nivalis; Marmota marmota latirostris; endangered alpine rodents; physical inactivity; the Western Carpathians

\section{Introduction}

Alpine ecosystems are the main accumulation sites of trace metals from the atmosphere [1-2]. According to studies on alpine-like sediments in the Eastern Tibetan Plateau, anthropogenic metals began to appear around 1950 , significantly increased in the 1980 s, and peaked in the mid-1990s. Over $80 \%$ of $\mathrm{Cd}, \mathrm{Pb}$ and $\mathrm{Zn}$ were

*e-mail: zuzana.ballova@uniza.sk quantified from anthropogenic emissions in atmospheric deposition since the mid-1990s atmosphere [3]. In Europe, the Western Carpathians are one of the most lead-polluted alpine regions [4]. Seasonal fluctuations in the lead concentrations in foliar parts of alpine plants and bones of feral pigeons have been recorded, with values higher in winter and early spring months than in summer months [1, 5-6].

In general, the presence of heavy metals in organisms shows the bioavailability of these heavy metals, which accumulate in plant parts and then subsequently are absorbed by animals. Prolonged 
exposure to heavy metals such as cadmium, copper, lead, nickel, and zinc can result in detrimental health effects [7-8]. Some of the most suitable bio-monitors of heavy-metal pollution are small terrestrial mammals [912]. Snow voles (Chionomys nivalis Martins, 1842) are very useful bio-monitors of heavy metal accumulation in alpine ecosystems. They are small, easy to catch, have a territory of limited range, a fairly short life span and are closely adjusted to their environment [11]. A study of snow voles showed that their winter diet could constitute a major pathway for the entry of $\mathrm{Pb}$ into the food web of alpine habitats [11].

However, early spring months could be more crucial than winter months to $\mathrm{Pb}$ accumulation [1, 11, 13]. Therefore, we decided to compare lead content in snow voles (active all seasons) to hibernating rodent species, whose activity begins in mid-April. Marmots have adapted to the cold stresses of their environment through the process of hibernation. Hypothermic preservation of tissues is an important thermoregulatory survival strategy that is used by rodents to diminish the effect of severe environmental conditions. It has been reported that the protective effect of hypothermia is realized by its effect on chemical toxicity as molecular and cellular processes [14-15]. Thus, we predict that hibernation could play a protective role in marmots. Alpine and subalpine habitats of the Western Carpathians are inhabited with the hibernating Tatra marmot (Marmota marmota latirostris Kratochvíl, 1964); an endemic subspecies of the alpine marmot that inhabits open areas in the Tatra Mountains and the Low Tatra Mountains. Within its native range, summer foraging areas are mainly located in tall-stem grasslands and tall-herb plant communities of Calamagrostion villosae and Trisetion fusci [16]. The home ranges of Tatra marmots and snow voles frequently overlap, and both species are glacial relicts. The winter diet of snow voles consists of mosses and lichens [17]. In early spring, when snow melts and marmots emerge from hibernation, preferred foods for both species include shoots and root crowns. These plant tissues are first available on the edges of the snow baths and snow fields, where atmospheric trace metals (mainly $\mathrm{Pb}$ ) accumulate [13].

Target organs for $\mathrm{Pb}$ accumulation in vertebrates are bones [18], but there is a difference in $\mathrm{Pb}$ accumulation between different types and parts of tooth and bone tissues [19-21]. Both species are endangered and protected, so we used only specimens acquired by nonlethal methods. The sample tissue type in snow voles was limited by its availability. $\mathrm{Pb}$ appeared in high concentration in the skull, ribs and caudal vertebrae, which each have a high lipid content [22]. Therefore, to expand the sample size we used the last tail vertebrae of snow voles. It was not necessary to kill the animals.

In marmots, perhaps the only non-invasive method of obtaining a sufficient number of samples is from individuals already dead. When analysing the occurrence of heavy metals in different parts of the skeletons, it was found that they tend to be mostly stored in the teeth [23]. In teeth, $\mathrm{Pb}$ concentration increases in cementum, while there is no such correlation in enamel $\mathrm{Pb}$ content [24]. The mandibular teeth (mainly molars) and the surrounding mandibular bones may reflect the exposure of mammals to lead in the environment [25]. During tooth development and dental tissue formation, heavy metals are deposited in dental tissues. Therefore, teeth can be used as bio-indicators that accurately reflect the environmental or dietary exposure of animals to heavy metals [26-27].

Bone is also a major storage organ for other trace metals. For example, bone can be a useful indicator of manganese exposure [28]. There is a possible correlation of different metal occurrence in animal and human tissues and the antagonistic role of other metals [29]. For example, significantly higher concentrations of lead and zinc were found in the bones than in the muscles of fish commercially harvested at sea [29]. A study on human femoral heads confirmed lead-cadmium and nickel-chromium interactions in bone samples. New types of interactions in specific parts of the femoral head were also noted: chromium-nickel in the articular cartilage; cadmium-manganese in the trabecular bone; and lead-chromium in the cortical bone [30]. Another study investigating trace elements in human femoral bones found that $\mathrm{Zn}$ and $\mathrm{Pb}$ significantly increased in the cement lines compared to the bone matrix. Different levels of $\mathrm{Pb}$ and $\mathrm{Sr}$ correlated with the degree of mineralization, while $\mathrm{Zn}$ content had no correlation with $\mathrm{Ca}$ levels [31]. Zinc co-accumulates with lead in the bones of vertebrates, and it is probable that increased zinc retention may result from active bone metabolism during egg formation or embryo development, as higher levels of $\mathrm{Zn}$ usually occur in the bones of females than males [32]. A mutual positive trend of accumulation of $\mathrm{Pb}$ and $\mathrm{Zn}$ may lead to the phenomenon where $\mathrm{Zn}$ may antagonize $\mathrm{Pb}$ toxicity by reducing tissue lead accumulation [33-34]. It is known that lead concentration levels affect the mineralization degree of bones [19]. Lead intoxication may reduce bone calcium concentration and some morphometric parameters, such as femoral head width [35].

We hypothesized that despite the similar spring diet and increased ability of teeth to accumulate $\mathrm{Pb}$ when compared to bones, the Tatra marmot as a hibernating species would have lower $\mathrm{Pb}$ content in their teeth than non-hibernating snow voles in their terminal tail vertebrae. With respect to the previously identified possible correlation between heavy metals, we assume that some elements appear together and affect the structure of teeth and the surrounding skull bones in marmots.

To confirm our hypothesis, we tried to answer the following questions: (1) Do contents of trace metals differ in marmots and snow voles? (2) Are there any differences in trace metal accumulation in teeth and skull bone tissues? (3) Is there a synergistic relationship between lead and other trace metals in teeth and bone tissues? 


\section{Materials and Methods}

\section{Sample Collection}

For heavy metal determination we used bone tissues from terminal tail vertebrae of snow voles (Chionomys nivalis) and teeth with skull bones (frontal and parietal) from Tatra marmots. The snow vole tails were collected

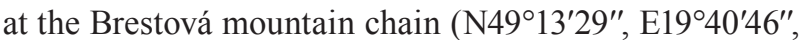
$1902 \mathrm{~m}$ a.s.l.) and the Dolina Bielych plies valley (Belianske Tatry Mts, N49¹3'26", E20¹3'17', 1673 m a.s.l.) in the Western Carpathians (Slovakia) during our previous studies, and were part of complex research on the atmospheric lead cycle in the alpine environment $[4$, 11]. We regularly sampled 61 individuals of $C$. nivalis in September 2009 and from May to November 2010. The study area included three sites of alpine meadows mixed with rocky fields. For detailed information about sampling see Janiga et al. [4, 11].

In cooperation with a project to rescue golden eagles, we obtained a unique collection of 44 Tatra marmot skulls with teeth from eagle nests. Some of the skulls were incomplete and therefore we used only frontal and parietal bones. We also compared concentrations of heavy metals in different teeth with various dentin/ enamel ratios, specifically molars and incisors.

\section{Analysis of Lead and Other Elements}

We performed two time- and material-independent experiments using two different methods.

AAS: We compared $\mathrm{Pb}$ content in snow vole tails and marmot teeth by electrothermal atomic absorption spectroscopy (AAS). Molars from 34 marmots extracted from skulls collected between 2006 and 2010 and terminal tail vertebrae from 61 snow voles were used in the AAS analysis to obtain detailed information on lead levels.

X-ray fluorescence: The second more rapid method we used to determine various elements in different marmot tissues (skull bones and teeth; molars and incisors separately) was X-ray fluorescence. This method was conducted to detect many elements ( $\mathrm{S}, \mathrm{Pb}, \mathrm{Fe}, \mathrm{Mn}, \mathrm{Cu}, \mathrm{K}, \mathrm{Ca}, \mathrm{Zn}, \mathrm{Mo}, \mathrm{Cr}, \mathrm{Ba}, \mathrm{Rb}, \mathrm{Sr}, \mathrm{Ti}$, $\mathrm{Zr}, \mathrm{Cl}$, As, Co, Cd, Sb, I) simultaneously. We used 88 samples (tooth and bone tissues) from 44 individual marmots.

\section{Estimation of $\mathrm{Pb}$ Content}

$\mathrm{Pb}$ content was determined by AAS (Perkin Elmer 1100B, Norwalk, Connecticut, USA) equipped with deuterium background correction and an HGA 700 graphite furnace with an automated sampler AS-70. The instrumental conditions were: wavelength $283.3 \mathrm{~nm}$; slit $0.7 \mathrm{~nm}$; lamp current $10 \mathrm{~mA}$.

The temperature programme was as follows: Drying 1:70/10/10; Drying 2:150/2/60; Pyrolysis: 800/15/30; Atomization: 1800/0/3; Cleaning: 2500/0/3 (temperature $\left({ }^{\circ} \mathrm{C}\right) /$ ramp time (s)/ hold time (s)). Deuterium background correction was used throughout the work.

To prepare calibration solutions, aliquots were taken from a certified stock standard solution 1000 mg..$^{-1}$ of $\mathrm{Pb}$ (Merck, Darmstadt, Germany). The calibration range was 5-20 $\mu \mathrm{g} \cdot \mathrm{l}^{-1}$. The matrix modifier $\mathrm{NH}_{4} \mathrm{H}_{2} \mathrm{PO}_{4}(0.2 \mathrm{mg})$ was used by the determination of $\mathrm{Pb}$.

The results were evaluated from the calibration curve, and the accuracy of the determination was proven by the standard addition technique. Standard addition calibration had to be applied, as the sample matrix depressed the absorption signal. Results of the three additions were accepted only when the linear regression equation had a fit of at least 0.99 . The detection limit, defined as three times the background noise, was $0.5 \mu \mathrm{g} / \mathrm{kg}$ for $\mathrm{Pb}$. Procedural blanks and calibration standards were taken through digestion and storage procedures to evaluate contamination from reagents and containers.

\section{Method of AAS Evaluation}

The absolute sensitivity, or characteristic mass $\left(\mathrm{m}_{\mathrm{o}}\right)$ for $\mathrm{Pb}$ was found to be $20 \mathrm{pg}$ in $20 \mu \mathrm{l}$ injection

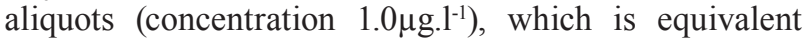
for bone- $\mathrm{Pb}$ of $0.05 \mu \mathrm{g} \cdot \mathrm{g}^{-1}$ (weight of bone $0.5 \mathrm{~g} / 25 \mathrm{ml}$; $0.2 \mathrm{~g} / 10 \mathrm{ml} ; 0.1 \mathrm{~g} / 5 \mathrm{ml}$ ).

The characteristic mass is defined as the mass of analyte required to produce an integrated absorbance of $0.0044 \mathrm{~s}$.

The method precision was better than $<5 \%$ $(\mathrm{RSD}=$ error of determination $=\mathrm{SD}$ in $\%)$.

The accuracy of the method was established by analyzing the reference material Bovine Liver No. 12-2-01 (Slovak Metrological Institute). The determined value $\left(0.70 \pm 0.05 \mathrm{mg} \cdot \mathrm{kg}^{-1}\right)$ agreed well with the certified value $\left(0.71 \pm 0.08 \mathrm{mg} \cdot \mathrm{kg}^{-1}\right)$, and within the uncertainty limit established for the material.

\section{Estimating Several Elements}

The samples were analyzed by X-ray fluorescence [36] using a hand-held XRF Spectrometer DELTA CLASSIC (USA). We used the CONOSTAN calibration standard. The handheld X-ray fluorescence was already used for scanning the elemental composition of biological samples, including horns, antlers, teeth and bones of various animal species, and it was demonstrated that a handheld XRF is an effective and accurate tool for biological and forensic investigation [37].

We put each sample into the modelling clay to avoid determination of the elements in other materials. We used multiple-beam measurement, in which every measurement consisted of 3 beams for 30 seconds, repeated three times, and then averaged. The following elements were detected: $\mathrm{P}, \mathrm{S}, \mathrm{Cl}, \mathrm{K}, \mathrm{Ca}, \mathrm{Ti}, \mathrm{Mn}, \mathrm{Fe}$, $\mathrm{Ni}, \mathrm{Zn}, \mathrm{Sr}, \mathrm{Ba}$ and $\mathrm{Pb}$. The results were given in 
Table 1. Lead content $(\mu \mathrm{g} / \mathrm{g})$ in two tissue types of snow voles and marmots (AAS - Perkin Elmer 1100B). Molars were collected from 34 animals (bones from 44 marmots from golden eagle nests were inspected). Samples from juveniles and adults were collected in an equal manner in both species.

\begin{tabular}{|c|c|c|c|c|}
\hline Taxon and tissue & Mean & SE & N & One-way ANOVA \\
\hline C. nivalis - tail vertebrae & 10.56 & 1.16 & 61 & \multirow{2}{*}{$\begin{array}{c}\mathrm{F}=0.18 \\
\mathrm{P}=0.66, \text { n.s. }\end{array}$} \\
\hline
\end{tabular}

PPM (part per million) units. Detection limit for each individual element was determined from such a sample in which the content of this element was at the limit of detection. The detection limits were evaluated from the combination of different settings of our spectrometer and verified by multiple measurements. The minimum value of a particular element represented the current detection limit of the spectrometer for the measured material.

Using the multiple testing of our bone samples we found minimum values of the concentrations of distinct elements that our instrument was able to measure. The minimum values are presented in Table 2. The Spectrometer DELTA CLASSIC is not designed for exact investigation of several light elements (mainly P), and because of that its absolute values are in very wide limits [38]. However, the ratios and variability of elements in samples are exactly applicable for multivariate statistics. For example, in the case of phosphorus, it is possible to use the values to measure its behavior against other elements (in PCA).

\section{Statistics}

Considering that the data was normally distributed, the element amounts among different groups were statistically compared using one-way ANOVA and Tukey's HSD test at the 95\% confidence level $(\mathrm{p}<0.05)$.

Principal component analysis (PCA) was used to determine main components, the component weights and the percentage of variation. One-way ANOVA of principal component scores was used to test the differences in mutual concentration of more elements in the tissues of marmots. All statistical analyses were performed with Statistica 12 software (Stat Soft CR, Prague, Czech Republic) for Windows.

\section{Results}

When we compared lead content in terminal tail vertebrae of snow voles and in marmot molars by AAS,

Table 2. The average values of the examined elements in the hard tissues (skull bones and teeth together) of Tatra marmots. 44 marmots were examined in total. For some elements, the means were calculated only from samples in which the amount of an element was above the detection limit of a DELTA CLASSIC spectrometer (e.g., S, Cl, Pb, etc.).

\begin{tabular}{|c|c|c|c|c|c|}
\hline Elements (ppm) & $\mathrm{N}$ & Mean & Minimum & Maximum & St. deviation \\
\hline $\mathrm{P}^{*}$ & 88 & 527828.4 & 304801 & 819692 & 86595.89 \\
\hline S & 31 & 2388.6 & 876 & 5084 & 966.07 \\
\hline $\mathrm{Cl}$ & 23 & 1960.5 & 1003 & 2605 & 409.25 \\
\hline K & 46 & 1033.5 & 466 & 1825 & 369.98 \\
\hline $\mathrm{Ca}$ & 88 & 375454.3 & 240981 & 546482 & 71854.28 \\
\hline $\mathrm{Ti}$ & 63 & 3605.6 & 97 & 9507 & 2154.29 \\
\hline $\mathrm{Mn}$ & 73 & 360.4 & 13 & 3167 & 624.36 \\
\hline $\mathrm{Fe}$ & 56 & 247.5 & 66 & 1264 & 178.06 \\
\hline $\mathrm{Ni}$ & 30 & 55.2 & 35 & 84 & 14.96 \\
\hline $\mathrm{Zn}$ & 88 & 191 & 38 & 516 & 106.51 \\
\hline $\mathrm{Sr}$ & 88 & 96.1 & 46 & 220 & 33.32 \\
\hline $\mathrm{Ba}$ & 15 & 70.7 & 41 & 164 & 31.44 \\
\hline $\mathrm{Pb}$ & 30 & 14.7 & 8 & 36 & 6.45 \\
\hline
\end{tabular}

*Considering that the hand-held XRF Spectrometer DELTA CLASSIC is designed for a very wide spectrum of measurements, the absolute values of light elements (mainly P) vary within wide intervals. However, the ratios and variability of elements in samples are correct. 
a)

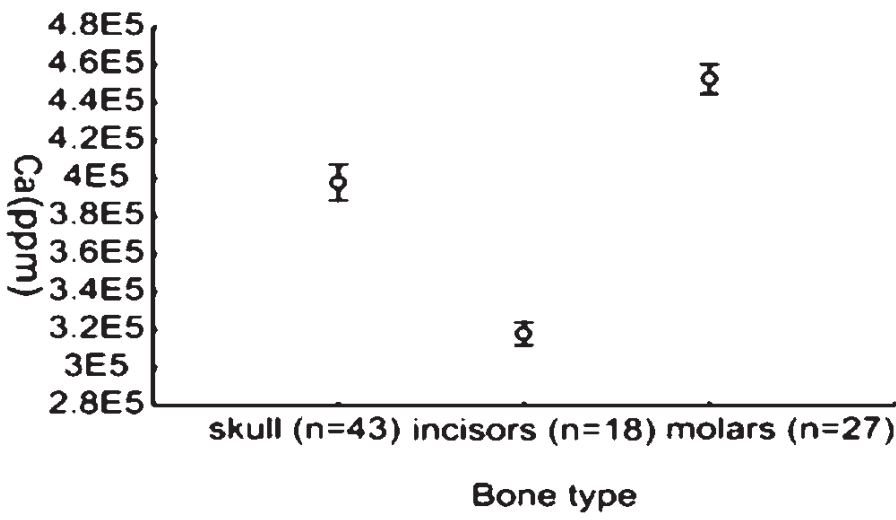

b)

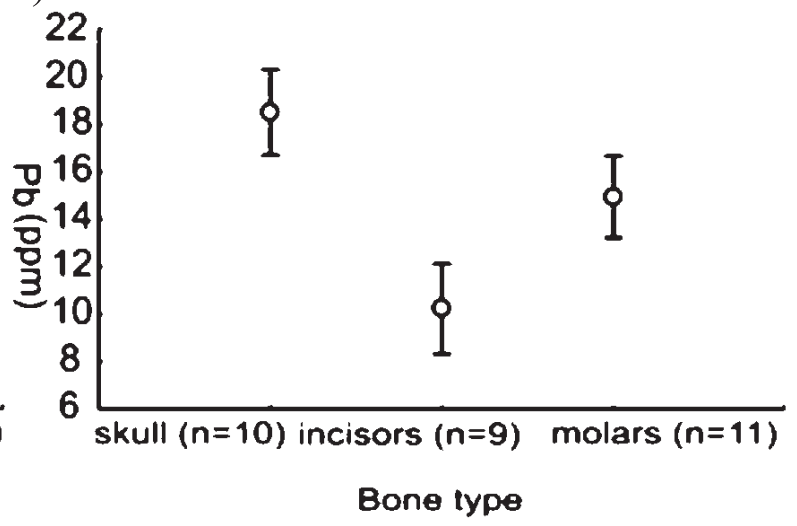

Fig. 1. A: Marmot molars contained more calcium than incisors or skull bones (one-way ANOVA, $F(2,85)=96.22, p=0.00001$ ). All groups differ at $\mathrm{p}<0.05$ (Tukey HSD test). $\mathrm{B}$ : Pb levels are higher in skull bones of marmots than in their molars and incisors (one-way ANOVA, $\mathrm{F}(2,27)=4.98, \mathrm{p}=0.01)$. All groups differ at $\mathrm{p}<0.05$ (Tukey HSD test).

we did not find any statistically significant difference (Table 1).

Using X-ray spectrometry we found that in Tatra marmot skull bones and teeth 13 elements were detected above the detection limit (Table 2). Eight heavy metals harmful for living organisms were found in the samples. Four of these are essential nutrients that are required for various biochemical and physiological functions $(\mathrm{Fe}$, $\mathrm{Mn}, \mathrm{Ni}$, and $\mathrm{Zn}$ ), and the other four are non-essential highly toxic metals with no biological function $(\mathrm{Ba}, \mathrm{Pb}$, $\mathrm{Ti}$, and $\mathrm{Sr}$ ).

\section{Lead-Calcium Interactions}

Marmot incisors accumulated less $\mathrm{Ca}$ and $\mathrm{Pb}$ than molars and skull bones (Fig. 1a, 1b).

The mutual interrelationship of $\mathrm{P}, \mathrm{Ca}, \mathrm{Sr}, \mathrm{Zn}, \mathrm{Pb}$ in the tissues was analyzed by principal component analysis (PCA). The first factor in PCA is a unipolar vector that generally reflects mutual increases or decreases of all five elements in the skull bones and teeth of marmots (Table 3). The antagonistic relationship between $\mathrm{Ca}$ and $\mathrm{Zn} / \mathrm{Pb}$ concentrations (factor 2) seems to be evidence that lead acts as a calcium substitute in marmot bones and teeth. Factor 3 mainly describes the antagonistic role between $\mathrm{Sr}$ and $\mathrm{Pb}$. Factor 4 is also a bipolar vector describing $\mathrm{Sr}$ increase and $\mathrm{P}$ decrease or vice versa (Table 3 ).

In the coaccumulation effect skulls and molars contained more $\mathrm{Pb}, \mathrm{Zn}, \mathrm{Sr}, \mathrm{Ca}$ and $\mathrm{P}$ than incisors. This factor probably also reflects the different tempo of element restoration in the incisors of rodents (Fig. 2).

Comparison of factor 2 scores reflects that $\mathrm{Pb}$ and $\mathrm{Zn}$ coaccumulate in marmot bones. When $\mathrm{Ca}$ increases, $\mathrm{Pb} / \mathrm{Zn}$ decrease or vice versa. Molars contained relatively more $\mathrm{Ca}$ and less $\mathrm{Pb} / \mathrm{Zn}$ than skulls or incisors (Fig. 3).

\section{Discussion}

Despite similar spring diet and higher ability of teeth to accumulate $\mathrm{Pb}$ when compared to bones [19], the teeth of hibernating Tatra marmots did not contain more lead than tail vertebrae of non-hibernating snow voles. The results indicate that longer-living marmots may accumulate less $\mathrm{Pb}$ than snow voles, which usually live no more than two years $[4,11]$. In the wild, Alpine marmots can live up to $13-15$ years [39], but a lifespan up to 18 years is possible [40]. No information

Table 3. Weights of components with the percentage of variation in principal component analysis of the five elements in the skull bones and teeth of Tatra marmots $(\mathrm{n}=30)$. For the number of tissue samples see Fig. 3.

\begin{tabular}{|c|c|c|c|c|c|}
\hline Variable & Factor 1 & Factor 2 & Factor 3 & Factor 4 & Factor 5 \\
\hline $\mathbf{P}$ & $\mathbf{- 0 . 8 5 3}$ & 0.208 & -0.009 & $\mathbf{0 . 4 4 9}$ & 0.168 \\
\hline $\mathbf{C a}$ & $\mathbf{- 0 . 6 6 7}$ & $\mathbf{0 . 6 9 1}$ & -0.145 & -0.186 & -0.151 \\
\hline $\mathbf{S r}$ & $\mathbf{- 0 . 8 2 3}$ & -0.085 & $\mathbf{0 . 4 2 8}$ & $\mathbf{- 0 . 3 0 8}$ & 0.193 \\
\hline $\mathbf{Z n}$ & $\mathbf{- 0 . 8 4 7}$ & $\mathbf{- 0 . 3 7 6}$ & 0.202 & 0.113 & -0.297 \\
\hline $\mathbf{P b}$ & $\mathbf{- 0 . 6 9 8}$ & $\mathbf{- 0 . 3 5 8}$ & $\mathbf{- 0 . 6 0 0}$ & -0.144 & 0.072 \\
\hline Variation (\%) & $\mathbf{6 1 . 0 7 8}$ & 15.923 & 12.097 & 7.281 & 3.622 \\
\hline
\end{tabular}




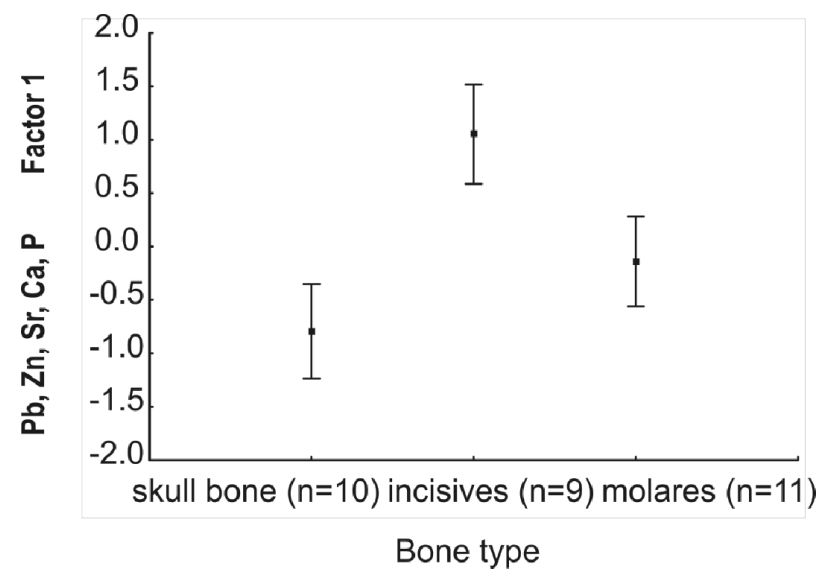

Fig. 2. Means with 0.95 confidence limits of the factor 1 scores (one-way ANOVA, F $(2,27)=17.8, \mathrm{p}=0.00001$ ). $\mathrm{Pb}, \mathrm{Zn}, \mathrm{Sr}$, $\mathrm{Ca}$ and $\mathrm{P}$ are accumulated more intensively in the skull bones than in the molars (lower numbers at y-axis mean higher levels of element concentrations, Tukey HSD test). The lowest concentration of these elements was in incisors.

is available on the lifespan of the Tatra marmot subspecies, but we can assume that it is similar to the alpine marmot.

Age is an important parameter to be taken into account when studying heavy-metal concentrations [41-42]. In bones and teeth in particular, $\mathrm{Pb}$ accumulates significantly with increasing age [43]. The bioaccumulation effect of $\mathrm{Pb}$ by age would indicate that marmot teeth contain relatively low amounts of $\mathrm{Pb}$ when compared to voles. Tatra marmots hibernate for seven (maximally eight) months from approximately the second half of September or early October to the second half of April or early May. Hibernation could protect them against an excessive intake of lead due to their not eating, and as a result of fluctuations in environmental temperatures. Acute toxicity of some heavy metals,

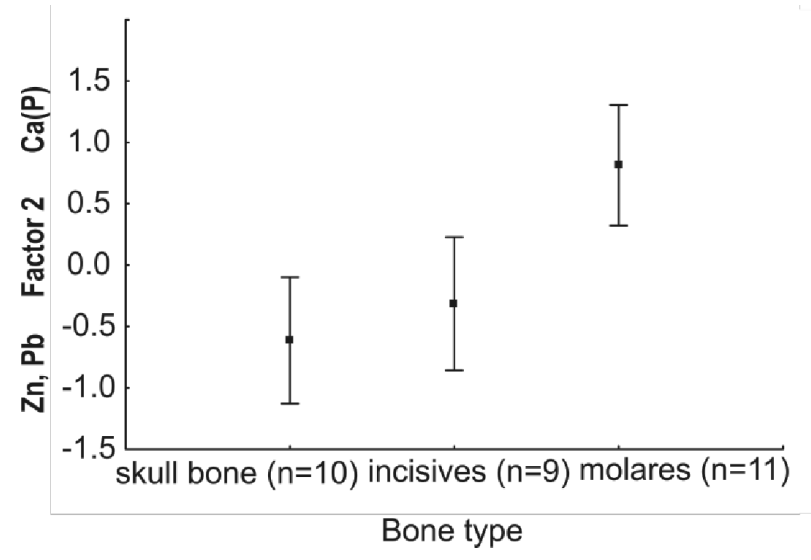

Fig. 3. Means with 0.95 confidence limits of the factor 2 scores (one-way ANOVA, F $(2,27)=9.5, p=0.00075$ ). The mutual concentration of lead and zinc was proportionally higher in skull bones and incisors than in molars when related to the amount of calcium (Tukey HSD test). organic solvents and agricultural chemicals can increase at higher as well as lower environmental temperatures [44], as may be the case in snow voles, which are active during all seasons. Additionally, the warmer core body temperature of mammals may enhance the toxicity of some drugs [14]. By contrast, hypothermia is protective and may have a clinical benefit for the prevention of toxicant injury [45].

Similar results to our findings were found in a study of the heavy metal concentrations in the livers of the longer-lived fat dormouse (Glis glis) and the shorterlived common vole (Microtus arvalis), in which the voles exhibited significantly higher values of heavy metals (mainly $\mathrm{Pb}$ and $\mathrm{Cd}$ ) [46]. The difference might be explained by the variance in two species' ecology (hibernation only in the fat dormouse, different habitats and feeding strategies). These biological and ecological differences are likely to result in differences in their potential for bioaccumulation of pollutants from the agricultural ecosystem they both inhabit [46].

The difference in $\mathrm{Pb}$ accumulation in snow voles and marmots may be caused to a minimal extent by their diet, as the winter diet of snow voles (mosses, lichens) could constitute a major pathway for the entry of $\mathrm{Pb}$ into the food chain of alpine habitats [11]. Bryophytes collect high concentrations of pollutants due to their physiological features [47] and are a priority indicator of trace metal contamination from atmospheric deposition in high mountain ecosystems [48]. Lichens are excellent bio-indicators of $\mathrm{Pb}$ air pollution in alpine areas [49]. Conversely, marmots do not eat anything during hibernation. In early spring, after emergence from hibernation, marmots encounter ground fully covered with snow or patches of snow. There is no green grass, and the animals are inactive and do little to no foraging [50]. During later spring, their diet consists of mainly plant roots and shoots [51], and lichens [52]. Roots and shoots contain the highest $\mathrm{Pb}$ concentration of plant organs [53-54]. Some metals - especially $\mathrm{Pb}$ - accumulate in plant roots, probably due to a physiological barrier against metal transport to aerial parts, while others - like $\mathrm{Cd}$ - are easily transported within the plants [55]. Fine roots intensely adsorbed and accumulated $\mathrm{Pb}$ of the A-horizon soil, resulting in high $\mathrm{Pb}$ concentrations in the bark of roots. Moreover, significant correlation was found between $\mathrm{Pb}$ concentrations in fine roots and soils. A-horizon confirms that fine roots could adsorb and accumulate $\mathrm{Pb}$ materials in soil [56].

Food spectrum analysis in snow voles showed that $12 \%$ of the investigated stomach contents consisted of insect remains, which represent about $6 \%$ of their total diet composition [57]. Tatra marmots only very occasionally consume animals as part of their diet, but generally this would occur at the beginning of their active season [58]. However, the majority of the diet of both species is comprised of green plants [17, 51-52, 57]. Most common among all green vegetable remains in the stomachs of snow voles were green fragments of 
Nardus stricta and Taraxacum officinale [57]. The plant Nardus stricta constituted $49 \%$ of the snow vole diet from Musala peak [17]. During summer, marmots also eat mainly grasses and herbs [59-60], their diet changes during the active season, reflecting available food sources [52]. Similarly, the snow vole diet also changes throughout the year, according to their phenology in a way similar to that of the marmot diet [61].

\section{Lead in Different Tissues}

Our presumption that teeth accumulate more $\mathrm{Pb}$ than bones was rebutted in marmots. Frontal and parietal skull bones contained significantly more $\mathrm{Pb}$ than marmot incisors, but skull bones did not contain significantly more lead than molars. Marmot incisors grow continually. Only the front surface of the incisor has enamel and the back is softer dentine [62]. The incisors renew themselves, whereas the static molars could reflect past exposure of heavy metals. According to the results of PCA there are obvious correlations among several elements. The first component represents the change of the contents of $\mathrm{P}, \mathrm{Ca}, \mathrm{Zn}, \mathrm{Sr}$ and $\mathrm{Pb}$ in the skull bones and teeth of marmots. In chicken bones the $\mathrm{Pb}$ adsorption capacities significantly positively correlated with total P content [63]. In a study on human articular cartilage and subchondral bone it was found that in contrast to $\mathrm{Pb}$ and $\mathrm{Zn}, \mathrm{Ca}$ and $\mathrm{Sr}$ showed a very homogeneous distribution in calcified cartilage and subchondral bone. However, Sr signals appeared to be relatively more decreased than $\mathrm{Ca}$ signals in areas of less calcified bone matrix [64].

\section{Hibernation and $\mathrm{Pb} / \mathrm{Zn}$ Versus $\mathrm{Ca}$ Concentrations in Bones}

We confirmed an antagonistic relationship between $\mathrm{Ca}$ and $\mathrm{Pb} / \mathrm{Zn}$ accumulation in the bone tissues and teeth of marmots (factor 2). Lead likely acts as a calcium substitute in marmot bones and teeth. Marmots and bears are able to prevent disuse osteoporosis during hibernation by preservation of bone mechanical, geometrical, mineral, and microstructural properties [65-66]. According to a study on bones of yellow-bellied marmots (Marmota flaviventris), possible mechanisms of bone preservation during hibernation have not yet been found [65]. However, proteomics data raises the possibility that the endocannabinoid system may be associated with it. Endocannabinoids are signalling molecules derived from fatty acids that appeared early in evolution and play an important role in regulating numerous physiological processes, including those that are altered in hibernation, such as bone, fat, and energy metabolism [67]. Molecular mechanisms preventing disuse bone loss were explained in hibernating black bears (Ursus americanus) through elevated expression of anabolic genes [68]. Disuse in non-hibernators causes unbalanced bone remodelling and bone loss with increased excretion of calcium. Hibernating animals (bears, marmots) maintain balanced bone remodelling and are capable of limiting loss of skeletal mass [69]. Parathyroid hormone may control calcium concentrations in the serum during hibernation [70]. However, no studies have been done on the accumulation of lead and other heavy metals in bones during hibernation. Marmots have a mechanism to keep calcium in their bones during hibernation and their bones retain strength throughout their lifetime in both active and inactive states $[65,71]$. Moreover, growth of sub-adult marmot bones proceeds during hibernation [71]. It is possible that these as yet unexplained mechanisms reduce lead deposition in their bones. Trabecular bone architecture and cortical bone geometrical and mechanical properties were not different between hibernating and active marmots, but bone marrow adiposity was significantly greater in hibernators. Of the 506 proteins identified in marmot bone, 40 were significantly different in abundance between active and hibernating marmots. Monoaglycerol lipase, which plays an important role in fatty acid metabolism and the endocannabinoid system, was 98-fold higher in hibernating marmots compared with summer marmots and may play a role in regulating the changes in bone and fat metabolism that occur during hibernation [67].

In human femoral bones, $\mathrm{Zn}$ accumulates simultaneously with $\mathrm{Pb}$ [72]. In growing rats it was found that while marginal $\mathrm{Zn}$ deficiency exacerbates bone $\mathrm{Pb}$ accumulation, it generally does not intensify lead toxicity. High supplementary $\mathrm{Zn}$ attenuates $\mathrm{Pb}$ accumulation but is detrimental for bone mineral density [73]. On the contrary, supplementation of diet with calcium may represent an important secondary prevention strategy aimed at reducing levels of lead in body tissues [74]. These findings are consistent with our results, where with decreasing $\mathrm{Ca}, \mathrm{Pb}$ and $\mathrm{Zn}$ increased and vice versa. On some scale, increasing amounts of $\mathrm{Zn}$ may attenuate increasing $\mathrm{Pb}$ accumulation. $\mathrm{Zn}$ appears to be an inherent component of the mineralization front in articular cartilage and thus it is associated with the metabolic activity in this zone. In contrast, $\mathrm{Pb}$ seems to be passively but selectively accumulated by the tidemark (a transitional zone that marks the junction between calcified and uncalcified cartilage) with time, after the mineralization front has halted its advance. As a result, regions with duplicated tidemarks exhibit increased $\mathrm{Zn}$ concentrations in both tidemarks, whereas the accumulation of $\mathrm{Pb}$ is much more distinct in the deep tidemark (older) than in the sup-tidemark (younger) [75].

$\mathrm{Pb}$ decreased with increasing $\mathrm{Sr}$ in marmot bones and teeth according to factor 3 in PCA. Absorbed strontium is distributed throughout the body but preferentially deposited in bones and teeth. The incorporation of strontium occurred in different levels into distinct bones, regions within the same bone and teeth [76]. In living systems, strontium, barium and lead tend to follow calcium as trace constituents during nutrient uptake, internal distribution and excretion 
within organisms [77]. Inadequate nutritional calcium intake significantly increases uptake of $\mathrm{Sr}$ in serum as well as in trabecular bone matrix [79]. Strontium $\left(\mathrm{Sr}^{2+}\right)$ stimulates bone formation and inhibits osteoclastic activity. It has been introduced into clinical practice as oral strontium ranelate medication against osteoporosis [78]. Strontium ranelate treatment contributes to the increased bone mineral density and is associated with an improvement in bone strength [79-81]. Strontium could originate in the isotope composition of rocks, as weathering and hydrologic cycles transport strontium, and due to bio-purification strontium penetrates from rocks into soils, from soils into plants, from plants into animals and then finally into the skeleton [82-83]. For different nutrient-consumer pairs in a remote subalpine ecosystem it was found that $\mathrm{Ca}$ was biopurified of $\mathrm{Sr}$ 3-fold, of $\mathrm{Ba} 16$-fold, and of $\mathrm{Pb} 100$-fold in going from rock to sedge leaves. In going from sedge leaf to vole, $\mathrm{Ca}$ was biopurified of $\mathrm{Sr} 4$-fold, of $\mathrm{Ba} 8$-fold, and of $\mathrm{Pb}$ 16 -fold. In going from meadow vole to pine marten, $\mathrm{Ca}$ was biopurified of $\mathrm{Sr} 6$-fold, of $\mathrm{Ba} 7$-fold, and of $\mathrm{Pb}$ 1.1fold [77]. In view of the above findings, strontium may be involved in reducing substitution of $\mathrm{Ca}$ by $\mathrm{Pb}$ and maintains bone strength during hibernation.

Factor 4 in PCA indicates that $\mathrm{Sr}$ decreased with increasing P. Similar results were found in a study on rats, where the skeletal ratio ${ }^{85} \mathrm{Sr} /{ }^{47} \mathrm{Ca}$ decreased as dietary phosphorus was increased [84]. After intraperitoneal injection of radioactive calcium and strontium, the skeletal retention of ${ }^{85} \mathrm{Sr}$ was about 25 per cent more on a diet containing 1.3 per cent phosphorus than on a diet containing 0.5 per cent phosphorus. Skeletal retention of calcium varied little. It was concluded that renal discrimination against strontium as well as intestinal absorption of calcium and strontium were affected by the phosphorus content of the diet, but in opposite directions [84].

\section{Conclusions}

We can conclude that hibernation may affect $\mathrm{Pb}$ accumulation due to physiological features (hypothermia, slow metabolic rate, maintain $\mathrm{Ca}$ concentration in bones) or due to ecological and behavioural constraints (no eating during hibernation and reduced food intake in early spring months). Hibernating marmots accumulated less $\mathrm{Pb}$ than the non-hibernating snow voles. Trace metals accumulated differently in teeth and skull bones of marmots. Frontal and parietal skull bones contained significantly more $\mathrm{Pb}$ than marmot incisors, which renew themselves, and would not reflect past exposure of heavy metals. However, the difference was not significant when comparing skull bones with molars. Molars are static and could reflect past exposures. $\mathrm{Pb}$ in bones and teeth acts as a Ca substitute, while Zn may slightly reduce $\mathrm{Pb}$ accumulation but not $\mathrm{Ca}$ degradation. $\mathrm{Pb}$ accumulation may also decrease when bone $\mathrm{Sr}$ increases, and $\mathrm{Sr}$ is highly related to $\mathrm{P}$ content.

\section{Acknowledgements}

This research was supported by the structural funds of EU-ITMS 26210120006. For assistance in field data collection we acknowledge our colleagues Z. Hrehová, M. Némethy, J. Graban, J. Solár, J. Kisková, M. Olekšáková, S. Kapustová, M. Lukáň, L. Cachovanová, O. Gura, D. Červinková, and students of the Institute of High Mountain Biology. The authors also thank M. Žemberyová and the scientific staff of the Department of Analytic Chemistry, Comenius University for their contribution regarding lead analyses. For English proofreading and improvement, we are indebted to native English-speaking editor A. Clarahan.

\section{Conflict of Interest}

The authors declare no conflict of interest.

\section{References}

1. JANIGA M. Potential Effects of Global Warming on Atmospheric Lead Contamination in the Mountains. In The Socio-Economic Causes and Consequences of Desertification in Central Asia; Behnke R., Ed., Springer: Dordrecht, Netherlands, 231, 2008.

2. BACARDIT M., CAMARERO L. Major and trace elements in soils in the Central Pyrenees-high altitude soils as a cumulative record of background atmospheric contamination over SW Europe. Environ. Sci. Pollut. Res. 17, 1606, 2010.

3. BING H., WU Y., ZHOU J., LI R., WANG J. Historical trends of anthropogenic metals in Eastern Tibetan Plateau as reconstructed from alpine lake sediments over the last century. Chemosphere, 148, 211, 2016a.

4. JANIGA M., HREHOVÁ Z., DIMITROV K., GERASIMOVA C., LOVARI S. Lead levels in the bones of snow voles Chionomys nivalis (Martins, 1842) (Rodentia) from European mountains: a comparative study of populations from the Tatra (Slovakia), Vitosha and Rila (Bulgaria). Acta Zool. Bulg. 68, 291, 2016.

5. JANIGA M., CHOVANCOVÁ B., ŽEMBERYOVÁ M., FARKAŠOVSKÁ I. Bone lead concentration in chamois Rupicapra rupicapra tatrica and sources of variation. In Proc. $2^{\text {nd }}$ World Conf. Mt. Ungulates, 145, 1998.

6. JANIGA M., ŽEMBERYOVÁ M. Lead concentration in the bones of the feral pigeons (Columba livia): Sources of variation relating to body condition and death. Arch. Environ. Contam. Toxicol. 35, 70, 1998.

7. SINGH R., GAUTAM N., MISHRA A., GUPTA R. Heavy metals and living systems: An overview. Indian J. Pharmacol. 43, 246, 2011.

8. FLORA G., GUPTA D., TIWARI A. Toxicity of lead: A review with recent updates. Interdiscip Toxicol. 5, 47, 2012.

9. AL SAYEGH PETKOVŠEK S., KOPUŠAR N., KRYŠTUFEK B. Small mammals as biomonitors of metal pollution: a case study in Slovenia. Environ. Monit. Assess., 186, 4261, 2014.

10. MARTINIAKOVÁ M., OMELKA R., STAWARZ R., FORMICKI G. Accumulation of lead, cadmium, nickel, 
iron, copper, and zinc in bones of small mammals from polluted areas in Slovakia. P. J. Environ. Stud. 21, 153, 2012.

11. JANIGA M., HREHOVÁ Z., KOSTKOVÁ-ZELINOVÁ V. Seasonal effects of lead uptake by snow vole Chionomys nivalis (Martins, 1842) in West Tatra Mts.: bone metal concentrations and hematological indices. Pol. J. Ecol. 60, 611, 2012.

12. BALLOVÁ Z., JANIGA M. Lead levels in the bones of small rodents from alpine and subalpine habitats in the Tian-Shan Mountains, Kyrgyzstan. Atmosphere, 9, 35, 2018.

13. JANIGA M. Uptake of atmospheric lead in Prunella collaris depends on seasons. Oecol. Mont. 11, 94, 2002.

14. LEON L.R. Thermoregulatory responses to environmental toxicants: The interaction of thermal stress and toxicant exposure. Toxicol. Appl. Pharmacol. 233, 146, 2008.

15. DAVE K.R., CHRISTIAN S.L., PEREZ-PINZON M.A., DREW K.L. Neuroprotection: lessons from hibernators. Comp. Biochem. Physiol. B: Biochem. Mol. Biol. 162, 1, 2012.

16. BALLOVÁ Z., ŠIBÍK J. Microhabitat Utilization of the Tatra Marmot (Marmota marmota latirostris) in the Western Carpathian Mountains, Europe. Arct. Antarct. Alp. Res. 47, 169, 2015.

17. BELCHEVA M., METCHEVA R., ARTINIAN A., NICOLOVA E. Assessment of toxic elements in the snow vole (Chionomys nivalis) and its food from Rila mountains. Observatoire de Montagne de Moussala OM2, 7, 276, 1998.

18. SILBERGELD E.K., SAUK J., SOMERMAN M., TODD A., MCNEILL F., FOWLER B., FONTAINE A., VAN BUREN J. Lead in bone: storage site, exposure source, and target organ. Neurotoxicology, 14, 225, 1993.

19. PEMMER B., ROSCHGER A., WASTL A., HOFSTAETTER J.G., WOBRAUSCHEK P., SIMON R., THALER H.W., ROSCHGER P., KLAUSHOFER K., STRELI C. Spatial distribution of the trace elements zinc, strontium and lead in human bone tissue. Bone, 57,184, 2013.

20. NGANVONGPANIT K., BROWN J.L., BUDDHACHAT K., SOMGIRD C., THITARAM C. Elemental analysis of Asian elephant (Elephas maximus) teeth using X-ray fluorescence and a comparison to other species. Biol. Trace Elem. Res., 170, 94, 2016.

21. NGANVONGPANIT K., BUDDHACHAT K., PIBOON P., KLINHOM S. The Distribution of Elements in 48 Canine Compact Bone Types Using Handheld X-Ray Fluorescence. Biol. Trace Elem. Res., 174, 93, 2016.

22. HONDA K., FUJISE Y., ITANO K., TATSUKAWA R. Composition of chemical components in bone of striped dolphin, Stenella coeruleoalba: distribution characteristics of heavy metals in various bones. Agric. Biol. Chem. 48, 677, 1984.

23. VALAŠKOVÁ M., JANIGA M. Metal contamination in vertebrates from the Tjan-Shan mountains. Oecol. Mont. 23, 1, 2014.

24. LIU H.Y., CHAO J.H., CHUANG C.Y., CHIU H.L., YANG C. W., SUN Y.C. Study of P, Ca, Sr, Ba and Pb levels in enamel and dentine of human third molars for environmental and archaeological research. Adv. Anthropol. 3, 71, 2013.

25. MALARA P., FISCHER A., MALARA B. Selected toxic and essential heavy metals in impacted teeth and the surrounding mandibular bones of people exposed to heavy metals in the environment. J. Occup. Med. Toxicol. 11, 56, 2016.

26. ASADUZZAMAN K., KHANDAKER M.U., BAHARUDIN N.A., AMIN Y.B., FAROOK M.S., BRADLEY D.A., MAHMOUD O. Heavy metals in human teeth dentine: A bio-indicator of metals exposure and environmental pollution. Chemosphere, 176, 221, 2017.

27. GUEDE I., ZULUAGA M.C., ORTEGA L.A., ALONSO-OLAZABAL A., MURELAGA X., PINA M., GUTIERREZ F.J. Analyses of human dentine and tooth enamel by laser ablation-inductively coupled plasma-mass spectrometry (LA-ICP-MS) to study the diet of medieval Muslim individuals from Tauste (Spain). Microchem. J. 130, 287, 2017.

28. O'NEAL S.L., HONG L., FU S., JIANG W., JONES A., NIE L.H., ZHENG W. Manganese accumulation in bone following chronic exposure in rats: Steady-state concentration and half-life in bone. Toxicol. Lett. 229, 93, 2014.

29. PERUGINI M., VISCIANO P., MANERA M., ZACCARONI A., OLIVIERI V., AMORENA M. Heavy metal (As, $\mathrm{Cd}, \mathrm{Hg}, \mathrm{Pb}, \mathrm{Cu}, \mathrm{Zn}, \mathrm{Se}$ ) concentrations in muscle and bone of four commercial fish caught in the central Adriatic Sea, Italy. Environ. Monit. Assess. 186, 2205, 2014.

30. BRODZIAK-DOPIERALA B., KWAPULINSKI J., KUSZ D., GAJDA Z., SOBCZYK K. Interactions Between Concentrations of Chemical Elements in Human Femoral Heads. Arch. Environ. Contam. Toxicol. 57, 203, 2009.

31. HUTTON M. The effects of environmental lead exposure and in vitro zinc on tissue delta-aminolevulinic acid dehydratase in urban pigeons. Comp. Biochem. Physiol. C Pharmacol. Toxicol. Endocrinol. 74, 441, 1983.

32. HUTTON M., GOODMAN G.T. Metal contamination of feral pigeons Columba livia from the London area: Part 1 Tissue accumulation of lead, cadmium and zinc. Environ. Pollut. Ser. A, 22, 207, 1980.

33. GANGOSO L., ÁlVAREZ-LLORET P., RODRÍGUEZNAVARRO A.A.B., MATEO R., HIRALDO F., DONÁZAR J.A. Long-term effects of lead poisoning on bone mineralization in vultures exposed to ammunition sources. Environ. Pollut. 157, 569, 2009.

34. KORDAS K. The "Lead Diet": Can dietary approaches prevent or treat lead exposure? J. Pediatr., 185, 224, 2017.

35. 35. BHARDWAJ P., RAI D.V. Effect of lead toxicity on bone calcium content and morphometric parameters. Int. J. Res. Med. Sci. 4, 177, 2016.

36. BUTLER O.T., CAIRNS W.R., COOK J.M., DAVIDSON C.M. Atomic spectrometry update - a review of advances in environmental analysis. J. Anal. At. Spectrom. 32, 11, 2017.

37. BUDDHACHAT K., KLINHOM S., SIENGDEE P., BROWN J.L., NOMSIRI R., KAEWMONG P., THITARAM CH., MAHAKKANUKRAUH P., NGANVONGPANIT K. Elemental analysis of bone, teeth, horn and antler in different animal species using non-invasive handheld X-ray fluorescence. PLoS One. 11, e0155458, 2016.

38. INNOV-X-SYSTEMS. Delta hhxrf analyzers. Limits of detection (lods). Innov-X Systems, Inc.: Woburn, USA, http://www.xrfrentals.com/images/documents/delta_ detectable_elememts.pdf. 
39. NOWAK R.M. Walker's Mammals of the World. Johns Hopkins University Press, 1936, 1999.

40. WEIGL R. Longevity of mammals in captivity; from the living collections of the world. Kleine Senckenberg-Reihe, Stuttgart, 214, 2005.

41. RAUTIO A., KUNNASRANTA M., VALTONEN A., IKONEN M., HYVÄRINEN H., HOLOPAINEN I.J., KUKKONEN J.V.K. Sex, Age, and Tissue Specific Accumulation of Eight Metals, Arsenic, and Selenium in the European Hedgehog (Erinaceus europaeus). Arch. Environ. Contam. Toxicol. 59, 642, 2010.

42. ANGELOVIČOVÁ M., JANIGA M. Heavy metals and some other elements in the teeth of the Tatra marmot (Marmota marmota latirostris). Oecol. Mont. 26, 33, 2018.

43. VIGHI M., BORRELL A., AGUILAR A. Bone as a surrogate tissue to monitor metals in baleen whales. Chemosphere, 171, 81, 2017.

44. KAZUO N., KANJIMATSUI, HIROKO N. Environmental temperature, a factor modifying the acute toxicity of organic solvents, heavy metals, and agricultural chemicals. Toxicol. Lett. 6, 67, 1980.

45. GORDON C.J., JOHNSTONE A.F., AYDIN C. Thermal stress and toxicity. Compr. Physiol. 4, 995, 2014.

46. MARKOV G. Residual heavy metal concentrations in the fat dormouse (Glis glis) in an agricultural region of Bulgaria. Peckiana, 8, 229, 2012.

47. GONZÁLEZ A.G., POKROVSKY O.S. Metal adsorption on mosses: toward a universal adsorption model. J. Colloid Interface Sci. 415, 169, 2014.

48. BING H., WU Y., ZHOU J., SUN H. Biomonitoring trace metal contamination by seven sympatric alpine species in Eastern Tibetan Plateau. Chemosphere, 165, 388, 2016b.

49. LOPPI S. Lichens as sentinels for air pollution at remote alpine areas (Italy). Environ Sci. Pollut. Res. 21, 2563, 2014.

50. VAN VUREN D., ARMITAGE K.B. Duration of snow cover and its influence on life-history variation in yellow -bellied marmots. Can. J. Zool. 69, 1755, 1991.

51. BIBIKOV D.I. Die Murmeltiere der Welt. Spektrum Akademischer Verlag: Heidelberg, Germany, 228, 1996.

52. KARC $\mathrm{P}$. A contribution to the knowledge about the population of the Alpine marmot (Marmota marmota L.) in the western part of the Low Tatras National Park (PrašiváDumbier). Naturae Tutela, 10, 79, 2006 [In Slovak].

53. CIRIAKOVÁ A. Heavy metals in the vascular plants of Tatra Mountains. Oecol. Mont. 18, 23, 2009.

54. CIRIAKOVÁ A., MURSALIEV N., ŠOLTÉS R., LUKÁŇ M., JANIGA M. Lead concentrations in soils and plants of two altitudinal transects in the Eastern Kyrgyz Tian Shan mountains - a preliminary study. Oecol. Mont. 20, 19, 2011.

55. KABATA-PENDIAS A., PENDIAS H. Trace elements in soils and plants. CRC press: Boca Raton, Florida, 1984.

56. LUO J., TANG R., SUN S., YANG D., SHE J., YANG P. Lead distribution and possible sources along vertical zone spectrum of typical ecosystems in the Gongga Mountain, eastern Tibetan Plateau. Atmos. Environ. 115, 132, 2015.

57. METCHEVA R., BELTCHEVA M., CHASSOVNIKAROVA T. The snow vole (Chionomys nivalis) as an appropriate environmental bioindicator in alpine ecosystems. Sci. Total. Environ. 391, 278, 2008.

58. BALLOVÁ Z., BALLO M., HOLKO L. First observations of occasional carnivory in Tatra marmots, Slovakia. North West J Zool. 12, 184, 2016.

59. CHOVANCOVÁ B., ŠOLTÉSOVÁ A. Trophic base and food activity of the Tatra marmot (Marmota marmota latirostris Kratochvíl, 1961). Proceedings of the works of the Tatra National Park, 28, 71, 1988 [In Slovak].

60. FRASE B.A., ARMITAGE K.B. Yellow-bellied marmots are generalist herbivores. Ethol. Ecol. Evol. 1, 353, 1989.

61. JANEAU G., AULAGNIER S. Snow vole - Chionomys nivalis (Martins 1842). IBEX J.M.E. 4, 1, 1997.

62. COX P.G., HAUTIER L. Evolution of the Rodents: Advances in Phylogeny, Functional Morphology and Development. Cambridge University Press, 2015.

63. PARK J.H., WANG J.J., KIM S.H., KANG S.W., CHO J.S., DELAUNE R.D., OK Y.S., SEO D.C. Lead sorption characteristics of various chicken bone part-derived chars. Environmental geochemistry and health. 18, 1, 2018.

64. ZOEGER N., ROSCHGER P., HOFSTAETTER J.G., JOKUBONIS C., PEPPONI G., FALKENBERG G., FRATZL P., BERZLANOVICH A., OSTERODE W., STRELI C., WOBRAUSCHEK P. Lead accumulation in tidemark of articular cartilage. Osteoarthr. Cartil. 14, 906, 2006.

65. WOJDA S.J., MCGEE-LAWRENCE M.E., GRIDLEY R.A., AUGER J., BLACK H.L., DONAHUE S.W. Yellowbellied Marmots (Marmota flaviventris) preserve bone strength and microstructure during hibernation. Bone, $\mathbf{5 0}$, 182, 2012.

66. MCGEE-LAWRENCE M., BUCKENDAHL P., CARPENTER C., HENRIKSEN K., VAUGHAN M., DONAHUE S. Suppressed bone remodeling in black bears conserves energy and bone mass during hibernation. J. Exp. Biol. 218, 2067, 2015.

67. DOHERTY A.H., ROTELIUK D.M., GOOKIN S.E., MCGREW A.K., BROCCARDO C.J., CONDON K.W., PRENNI J.E., WOJDA S.J., FLORANT G.L., DONAHUE S.W. Exploring the Bone Proteome to Help Explain Altered Bone Remodeling and Preservation of Bone Architecture and Strength in Hibernating Marmots. Physiol. Biochem. Zool. 89, 364, 2016.

68. FEDOROV V.B., GOROPASHNAYA A.V., TØIEN Ø., STEWART N.C., CHANG C., WANG H., YAN J., SHOWE L.C., SHOWE M.L.K., DONAHUE S.W., BARNES B.M. Preservation of bone mass and structure in hibernating black bears (Ursus americanus) through elevated expression of anabolic genes. Funct. Integr. Genomics, 12, 357, 2012.

69. DOHERTY A.H., FLORANT G.L., DONAHUE S.W. Endocrine Regulation of Bone and Energy Metabolism in Hibernating Mammals. Integr. Comp. Biol. 54, 463, 2014.

70. DONAHUE S.W., GALLEY S.A., VAUGHAN M.R., PATTERSON-BUCKENDAHL P., DEMERS L.M., VANCE J.L., MCGEE M. E. Parathyroid hormone may maintain bone formation in hibernating black bears (Ursus americanus) to prevent disuse osteoporosis. J. Exp. Biol. 209, 1630, 2006.

71. DOHERTY A.H., FRAMPTON J.D., VINYARD C.J. Hibernation does not reduce cortical bone density, area or second moments of inertia in woodchucks (Marmota monax). J. Morphol. 273, 604, 2012.

72. ZIOŁA-FRANKOWSKA A., KUBASZEWSKI Ł., DĄBROWSKI M., KOWALSKI A., ROGALA P., STRZYŻEWSKI W., ŁABEDŹ W., UKLEJEWSKI R., NOVOTNY K., KANICKY V., FRANKOWSKI M. The Content of the 14 Metals in Cancellous and Cortical Bone of the Hip Joint Affected by Osteoarthritis. BioMed. Res. Int. 2015, 23, 2015.

73. JAMIESON J.A., TAYLOR C.G., WEILER H.A. Marginal zinc deficiency exacerbates bone lead accumulation and high dietary zinc attenuates lead accumulation at the 
expense of bone density in growing rats. Toxicol. Sci. 92, 286, 2006.

74. WANG H., SHI H., CHANG L., ZHANG X., LI J., YANG Y., JIANG Y. Association of blood lead with calcium, iron, zinc and hemoglobin in children aged 0-7 years: a large population-based study. Biol. Trace Elem. Res. 149, 143, 2012.

75. ROSCHGER A., HOFSTAETTER J.G., PEMMER B., ZOEGER N., WOBRAUSCHEK P., FALKENBERG G., SIMON R., BERZLANOVICH A., THALER H.W., ROSCHGER P., KLAUSHOFER K., STRELI C. Differential accumulation of lead and zinc in doubletidemarks of articular cartilage. Osteoarthr. Cartil. 21, 1707, 2013.

76. OLIVEIRA J.P., QUERIDO W., CALDAS R.J., CAMPOS A.P.C., ABRAÇADO L.G., FARINA M. Strontium is incorporated in different levels into bones and teeth of rats treated with strontium ranelate. Calcif. Tissue Int. 91, 186, 2012.

77. PEMMER B., HOFSTAETTER J.G., MEIRER F., SMOLEK S., WOBRAUSCHEK P., SIMON R., FUCHS R.K., ALLEN M.R., CONDON K.W., REINWALD S., PHIPPS R.J., BURR D.B., PASCHALIS E.P., KLAUSHOFER K., STRELI C., ROSCHGER P. Increased strontium uptake in trabecular bone of ovariectomized calcium-deficient rats treated with strontium ranelate or strontium chloride. J. Synchrotron Radiat. 18, 835, 2011.
78. BONNELYE E., CHABADEL A., SALTEL F., JURDIC, P. Dual effect of strontium ranelate: Stimulation of osteoblast differentiation and inhibition of osteoclast formation and resorption in vitro. Bone. 42, 129, 2008.

79. CATTANI-LORENTE M., RIZZOLI R., AMMANN P. In vitro bone exposure to strontium improves bone material level properties. Acta Biomater. 9, 7005, 2013.

80. JOBKE B., BURGHARDT A.J., MUCHE B., HAHN M., SEMLER J., AMLING M., MAJUMDAR S., BUSSE B. Trabecular reorganization in consecutive iliac crest biopsies when switching from bisphosphonate to strontium ranelate treatment. PLoS One. 6, e23638, 2011.

81. WU Y., ADEEB S.M., DUKE M.J., MUNOZ-PANIAGUA D., DOSCHAK M.R. Compositional and material properties of rat bone after bisphosphonate and/or Strontium ranelate drug treatment. J Pharm Pharm Sci. 16, $52,2013$.

82. BENTLEY R.A. Strontium Isotopes from the Earth to the Archaeological Skeleton: A Review. J. Archaeol. Method. Th. 13, 135, 2006.

83. HARTMAN G., RICHARDS M. Mapping and defining sources of variability in bioavailable strontium isotope ratios in the Eastern Mediterranean. Geochim. Cosmochim. Acta. 1, 126, 2014.

84. KOSTIAL K., LUTKIĆ A., GRUDEN N., VOJVODIĆ S., HARRISON G. E. The Effect of Dietary Phosphorus on the Metabolism of Calcium and Strontium in the Rat. Int. J. Radiat. Biol. Relat. Stud. Phys. Chem. Med. 6, 431, 1963. 